\title{
The relationship between top management turnover with earnings management and default risk and earnings forecast error in the Tehran Stock Exchange
}

\author{
Mohammad Khodaei Valahzaghard $^{\mathrm{a}^{*}}$ and Maryam Mirzamomen $^{\mathrm{b}}$
}

${ }^{a}$ Assist. Prof, Department of Financial Management, Science and Research branch, Islamic Azad university (IAU), Tehran, Iran ${ }^{b}$ M.Sc. Student, Department of Financial Management, Science and Research branch, Islamic Azad university (IAU), Tehran, Iran

\section{H R O N I C L E A B S T R A C T}

Article history:

Received October 27, 2012

Received in revised format

29 January 2013

Accepted 19 February 2013

Available online

February 222013

Keywords:

Top Management Turnover

Earnings Management

Default Risk

Earnings Forecast Error

\begin{abstract}
In this paper, we present a study to measure the relationship between top management turnover with earnings management and default risk and earnings forecast error in the Tehran Stock Exchange. The proposed study selects necessary information from 117 firms from the exchange over the period 2005-2010 and, using ordinary least squares technique as well as Pearson correlation ratios, examine three hypotheses of this paper. The results of the survey indicate that there are some meaningful relationships between change in top management with earning management, default risk and earning forecast error.
\end{abstract}

\section{Introduction}

During the past two decades, there have been various studies on relationship between earning management and top management changes (Degeorge et al., 1995; Firt et al., 1995; Degeorge et al., 1999). Call et al. (2009) studied whether analysts' earnings forecasts were more accurate when they also issued cash flow forecasts. They reported that (i) analysts' earnings forecasts issued together with cash flow forecasts were more accurate than those not accompanied by cash flow forecasts. In addition, they stated that analysts' earnings forecasts could reflect a better understanding of the implications of current earnings for future earnings when they were accompanied by cash flow forecasts. According to Agarwal and Taffler (2008), many developed corporate bankruptcy prediction techniques use a contingent claims valuation approach. They reported that the two approaches capture various aspects of bankruptcy risk, and while there was little difference in their predictive ability in the UK, the z-score approach could somewhat lead to greater bank profitability in conditions of differential decision error costs and competitive pricing regime.

Corresponding author. Tel: +98-912-3443139

E-mail: mohamadkhodaei@yahoo.com (M. Khodaei)

(C) 2013 Growing Science Ltd. All rights reserved. doi: $10.5267 /$ j.msl.2013.02.019 
Burgstahler and Dichev (1997) provided some evidence that firms manage reported earnings to prevent earnings decreases and losses. They found some evidence that two components of earnings, cash flow from operations and changes in working capital, could be implemented to reach increases in earnings. Dechow et al. (2003) investigated whether boosting of discretionary accruals to report a small profit could describe this "kink" and investigated and discussed a number of alternative explanations for the kink.

Brockman and Turtle (2003) proposed a model for firm security valuation based on path-dependent, barrier option models instead of the commonly implemented path-independent approach. They argued that path dependency was an intrinsic and fundamental characteristic of corporate securities because equity could be knocked out whenever a legally binding barrier is breached. Brookman and Thistle (2009) investigated CEOs' risk of termination, its determinants and its impact on firm value based on survival analysis and reported that the risk of termination could increase for about thirteen years before decreasing slightly with CEO tenure; $82 \%$ of CEOs had tenure of less than thirteen years. Bergstresser and Philippon (2006) provided some evidence that the implementation of discretionary accruals to manipulate reported earnings was more pronounced at firms where the CEO's potential total compensation was more closely tied to the value of stock and option holdings.

Hillegeist et al. (2004) made an assessment on whether two accounting-based measures, Altman's (1968) Z-Score and Ohlson's (1980) O-Score, effectively summarize publicly-available information about the probability of bankruptcy. They reported that researchers could use BSM-Prob instead of ZScore and O-Score in their studies and reach the SAS code to calculate BSM-Prob. Gong (2011) examined the relationship between CEO compensation and shareholder value added over CEO tenure. The research design studied two fundamental attributes of CEO compensation and shareholder value added. They reported that $\mathrm{CEO}$ receiving higher nominal or realized pay generating more shareholder value. Jog and McConomy (2003) investigated the effect of one such mechanism, namely voluntary disclosure of management earnings forecasts by issuers of IPOs, as a means of reducing asymmetric data as well as ex ante uncertainty. They reported that firms whose forecasts turn out to be optimistic were penalized compared with other forecasters and non-forecasters. Ting (2011) stated that corporates with higher default risk could more likely change their top management in the next financial reporting period and firms default less than other companies.

In this paper, we present a study to measure the impact of top management change on some financial figures. The proposed study of this paper first explains details of models in section 2, the results are given in section 3 and concluding remarks are given at the end.

\section{The proposed study}

We first present how to calculate each variables associated with the proposed study of this paper. To calculate default risk, we using the following

$$
\begin{aligned}
\text { Risk }_{i, t-1} & =x_{0}+x_{1} \text { CEOChange }_{i t}+x_{2} \text { CEOchange }_{i t-1}+x_{3} \text { Debt }_{i t}+x_{4} \text { ROA }_{i t} \\
& +x_{5} \text { LnAsset }_{i t}+x_{6} \text { Same }^{\text {Dit }} r_{i t}+x_{7} \text { Direct }_{i t}+x_{8} y_{i t}^{01}+x_{9} y_{i t}^{02}+x_{10} y_{i t}^{03}+x_{11} y_{i t}^{04}+x_{12} y_{i t}^{05}+\varepsilon_{i t},
\end{aligned}
$$

where CEOchange $i t$ is the change in management, Debt $t_{i t}$ is the debt ratio, LnAsset $_{i t}$ is the natural logarithm of total assets, Direct $_{i t}$ is the natural logarithm of total assets, and all $y$ variables are dummy variables, which receive one when we collect the information of the same year and zero, otherwise. In addition, we use the following to calculate $D D$,

$D D=\frac{\ln \left(\frac{V_{A}}{X_{t}}\right)+\left(\mu-0.5 \sigma_{A}^{2}\right) t}{\sigma_{A} \sqrt{A}}$, 
where $V_{A}$ represents total assets, $X_{t}$ denotes book value of total debts, $t$ is due time of debts, which is normally considered as one year, $\sigma_{\mathrm{A}}$ is the standard deviation of total assets and finally $\mu$ is the relative growth rate of total assets. In addition, $D P$, is calculated as follows,

$D p=1-e^{-z-\text { score }} /\left(1+e^{-z-\text { score }}\right)$,

where z-score is the Altman bankruptcy ratio, which is calculated as follows,

$Z=1.2 X_{1}+1.4 X_{2}+3.3 X_{3}+0.6 X_{4}+0.999 X_{5}$,

where $X_{1}$ is equal to working capita divided by total assets, $X_{2}$ is equal to accumulated profit divided by total assets, $X_{3}$ is equal to earning before tax and interest divided by total assets, $X_{4}$ is equal to market value divided by total assets and finally $X_{5}$ is equal to total sales by total assets. In order to study the relationship between change in management and earning management we use the following regression model,

$$
\begin{aligned}
D_{i, t-1}= & x_{0}+x_{1} \text { CEOchange }_{i t}+x_{2} \text { CEOchange }_{i t-1}+x_{3} \text { Debt }_{i t}+x_{4} \text { ROA }_{i t} \\
& +x_{5} \text { LnAsset }_{i t}+x_{6} \text { Same }^{\text {Dit }} \text { Dit }_{i t}+x_{7} \text { Direct }_{i t}+x_{8} y_{i t}^{01}+x_{9} y_{i t}^{02}+x_{10} y_{i t}^{03}+x_{11} y_{i t}^{04}+x_{12} y_{i t}^{05}+\varepsilon_{i t},
\end{aligned}
$$

In our study, total accruals $(T A)$ is estimated based on change in current assets $\left(\triangle C A_{i, t}\right)$, change in total current liabilities $\left(\triangle C L_{i, t}\right)$, change in cash $\left(\triangle C A S H_{i, t}\right)$, current portion of long-term debt $\left(\triangle S T D_{i, t}\right)$ and depreciation cost $\left(D E P_{i, t}\right)$ and $A_{i, t-1}$ is total assets of firms $i$ in year $t-1$ as follows,

$$
T A_{i, t-1}=\left(\Delta C A_{i, t}-\Delta C L_{i, t}-\Delta \operatorname{Cash}_{i, t}+\Delta S T D_{i, t}-\operatorname{Dep}_{i, t}\right) / A_{i, t-1} .
$$

Once we calculate $T A_{i, t-1}$ we need to calculate $\alpha_{1}, \alpha_{2}$ and $\alpha_{3}$ are calculated as follows,

$$
T A_{i, t-1}=\alpha_{0}+\alpha_{1}\left(A_{i, t-1}^{-1}\right)+\alpha_{2}\left(\Delta R E V_{i, t}\right)+\alpha_{3}\left(P P E_{i, t}\right)+\varepsilon_{i, t} .
$$

where $\triangle R E V_{i, t}$ is the change in revenue from year $t-1$ to year $t, P P E_{i t}$ is the growth value of equipment. Therefore, we have,

$N D A_{i, t}^{2}=\alpha_{0}+\alpha_{1}\left(A_{i, t-1}^{-1}\right)+\alpha_{2}\left(\Delta R E V_{i, t}\right)+\alpha_{3}\left(P P E_{i, t}\right)+\varepsilon_{i, t}$,

where $N D A$ represents non-discretionary accruals and finally discretionary accrual is calculated as follows,

$$
D A_{i, t}^{2}=T A_{i, t}-N D A_{i, t}^{2} \text {. }
$$

In order to study the relationship between change in management and earnings forecast error $(F E)$ we use the following regression model,

$$
\begin{aligned}
F E_{i, t-1}= & x_{0}+x_{1} \text { CEOchange }_{i t}+x_{2} \text { CEOchange }_{i t-1}+x_{3} \text { Debt }_{i t}+x_{4} \text { ROA }_{i t} \\
& +x_{5} \text { LnAsset }_{i t}+x_{6} \text { Same } \text { Dir }_{i t}+x_{7} \text { Direct }_{i t}+x_{8} y_{i t}^{01}+x_{9} y_{i t}^{02}+x_{10} y_{i t}^{03}+x_{11} y_{i t}^{04}+x_{12} y_{i t}^{05}+\varepsilon_{i t} .
\end{aligned}
$$

Note that $F E$ is calculated as follows,

$$
F E=\frac{\mid{ }_{E P S_{t-1}}-\text { FORE }_{t-1} \mid}{P_{t-1}}
$$

where $Y E P S_{t-1}, R O R E_{t-1}$ and $P_{t-1}$ are actual income, predicted income and last stock price, respectively. In order to do regression analysis, we need to know the data are normally distributed using Kolmogorov-Smirnov test and Table 1 shows details of our survey. 


\section{Table 1}

The results of Kolmogorov-Smirnov test

\begin{tabular}{llll}
\hline Figures & DA & FE & RISK \\
\hline Number of observations & 504 & 585 & 585 \\
Mean & 2.9049 & -48288.8467 & .9743 \\
Standard deviation & .33199 & 166904.25324 & .03661 \\
Absolute of changes & .032 & .337 & .241 \\
Maximum positive change & .032 & .336 & .241 \\
Maximum negative change & -.029 & -.337 & -.189 \\
Z & .710 & 8.153 & 5.832 \\
Sig. & .695 & .000 & .000 \\
\hline
\end{tabular}

As we can observe from Table 1, there are two variables maintain Sig. value of 0.000 , which are less than 0.05 and we can conclude that they are not normally distributed. Therefore, we take natural logarithm and repeat the tests summarized in Table 2.

Table 2

The results of Kolmogorov-Smirnov test

\begin{tabular}{lccc}
\hline Figures & DA & LNFE & LNRISK \\
\hline Number of observations & 504 & 585 & 585 \\
Mean & 2.9049 & 18.2145 & -.0538 \\
Standard deviation & .33199 & 3.99148 & .08412 \\
Absolute of changes & .032 & .061 & .261 \\
Maximum positive change & .032 & .061 & .261 \\
Maximum negative change & -.029 & -.048 & -.207 \\
$Z$ & .710 & 1.472 & 6.322 \\
Sig. & .695 & .062 & .568 \\
\hline
\end{tabular}

The results of Table 2 clearly indicate that the data are normally distributed and we can use ordinary least square techniques.

\section{The results}

In this section, we present details of our findings on testing three hypotheses of this survey.

\subsection{The results of the first hypothesis: The relationship between change management and default risk}

To examine the first hypothesis of this survey we use Pearson correlation ratio between change management and default risk as follows,

$$
\begin{cases}H_{0}: & \rho=0 \\ H_{1}: & \rho \neq 0\end{cases}
$$

The result of Pearson correlation test is equal to 0.778 , which means there is a relationship between these two variables

\section{Table 3}

The results of regression analysis on Eq. (1)

\begin{tabular}{cccccc}
\hline Model & $\begin{array}{c}\text { Pearson } \\
\text { correlation }\end{array}$ & $\begin{array}{c}\text { Determinant } \\
\text { coefficient }\end{array}$ & $\begin{array}{c}\text { Adjusted } \\
\text { determinant }\end{array}$ & $\begin{array}{c}\text { Standard } \\
\text { error }\end{array}$ & $\begin{array}{c}\text { Durbin } \\
\text { Watson }\end{array}$ \\
\hline 1 & $.778^{\mathrm{a}}$ & .605 & .580 & .03347 & 1.699 \\
\hline${ }^{\mathrm{a}}$ Level of Significance $=5 \%$ & & & &
\end{tabular}


Table 4 shows details of ANOVA test for regression analysis on Eq. (1). As we can observe from the results of Table 4, F-value is statistically significant and we can confirm the results of our regression analysis.

\section{Table 4}

The results of ANOVA test

\begin{tabular}{ccccccc}
\hline & Model & Sum of Square & Df & Mean square & F value & Sig. \\
\hline 1 & Regression & .300 & 11 & .027 & 24.332 & $.000^{\mathrm{a}}$ \\
& Residual & .196 & 175 & .001 & & \\
\cline { 2 - 7 } & Total & .496 & 186 & & & \\
\hline${ }^{\mathrm{a}}$ Level of Significance $=5 \%$ & & & & &
\end{tabular}

\section{Table 5}

The results of regression analysis

\begin{tabular}{cccccccc}
\hline & \multicolumn{2}{c}{$\begin{array}{c}\text { Non-standard coefficients } \\
\text { Coefficient }\end{array}$} & $\begin{array}{c}\text { Standar } \\
\text { Beta }\end{array}$ & t-student & \multicolumn{2}{c}{ Sig, } & \multicolumn{2}{c}{ Collinearity } \\
Varianc & Factor \\
\hline (Constant) & .093 & .038 & & 2.449 & .015 & \\
CEOCHANGEit & 2.909 & .120 & .041 & 24.340 & .000 & .840 & 1.190 \\
CEOCHANGEit1 & 7.523 & .312 & .028 & 24.111 & .000 & .973 & 1.028 \\
DEBT & -.109 & .017 & -.415 & -6.494 & .000 & .552 & 1.812 \\
ROA & .229 & .035 & .417 & 6.595 & .000 & .564 & 1.772 \\
LNASSET & -.003 & .001 & -.119 & -2.408 & .017 & .928 & 1.078 \\
SAMEDIR & -.945 & .112 & -.009 & -8.418 & .000 & .878 & 1.138 \\
DIRECT & -.990 & .111 & -.002 & -8.901 & .000 & .878 & 1.128 \\
Y1 & 2.511 & .199 & .011 & 12.601 & .000 & .863 & 1.159 \\
Y2 & -.005 & .008 & -.039 & -.639 & .524 & .608 & 1.644 \\
Y3 & -.003 & .008 & -.020 & -.323 & .747 & .598 & 1.672 \\
Y4 & .004 & .008 & .028 & .454 & .650 & .602 & 1.661 \\
Y5 & -.002 & .008 & -.012 & -.196 & .845 & .584 & 1.713 \\
\hline
\end{tabular}

As we can observe from the results of Table 5, there is a meaningful and positive relationship between change management and risk default. Therefore, the first hypothesis of this survey has been confirmed.

\subsection{The results of the second hypothesis: The relationship between change management and earning management}

To examine the first hypothesis of this survey we use Pearson correlation ratio between change management and earning management as follows,

$$
\begin{cases}H_{0}: & \rho=0 \\ H_{1}: & \rho \neq 0\end{cases}
$$

The result of Pearson correlation ratio between these two variables is equal to 0.863 , which means there is a positive and meaningful relationship between these two variables. Table 6 shows details of our findings on basic statistics on the regression model.

\section{Table 6}

The results of some basic statistics

\begin{tabular}{cccccc}
\hline Model & $\begin{array}{c}\text { Pearson } \\
\text { correlation }\end{array}$ & $\begin{array}{c}\text { Determinant } \\
\text { coefficient }\end{array}$ & Adjusted determinant & Standard error & Durbin Watson \\
\hline 1 & $.863^{\mathrm{a}}$ & .694 & .508 & .93213 & 1.914 \\
\hline${ }^{\mathrm{a}}$ Level of Significance $=5 \%$ & & & &
\end{tabular}


The result of Durbin-Watson indicates that there is no auto-correlation among different residuals. Table 7 shows the results of ANOVA test.

Table 7

The results of ANOVA test

\begin{tabular}{ccccccc}
\hline & Model & Sum of Square & Df & Mean square & F value & Sig. \\
\hline \multirow{2}{*}{1} & Regression & 1.070 & 12 & .915 & 9.567 & $.000^{\mathrm{a}}$ \\
& Residual & 14.352 & 150 & .096 & & \\
\cline { 2 - 6 } & Total & 15.422 & 162 & & & \\
\hline
\end{tabular}

The results of Table 8 indicate that there is a meaningful and linear relationship between independent variable and dependent variable.

Table 8

The results of regression analysis

\begin{tabular}{|c|c|c|c|c|c|c|c|}
\hline & \multicolumn{2}{|c|}{ Non-standard coefficients } & \multirow{2}{*}{$\begin{array}{c}\text { Standard } \\
\text { coefficient } \\
\text { Beta } \\
\end{array}$} & \multirow{2}{*}{ t-student } & \multirow{2}{*}{ Sig, } & \multicolumn{2}{|c|}{ Collinearity Statistics } \\
\hline & $\mathrm{B}$ & Coefficient & & & & & $\mathrm{B}$ \\
\hline (Constant) & 2.370 & .381 & & 6.227 & .000 & & \\
\hline CEOCHANGE $_{i t}$ & .806 & .053 & .130 & 15.099 & .001 & .837 & 1.195 \\
\hline CEOCHANGE $_{\mathrm{it}-1}$ & .686 & .124 & .109 & 5.514 & .002 & .956 & 1.046 \\
\hline DEBT & .968 & .165 & .002 & 5.849 & .002 & .594 & 1.684 \\
\hline ROA & .316 & .036 & .088 & 8.718 & .001 & .603 & 1.659 \\
\hline LNASSET & .881 & .054 & .114 & 16.441 & .000 & .911 & 1.097 \\
\hline SAMEDIR & .942 & .124 & .020 & 7.579 & .003 & .446 & 2.240 \\
\hline DIRECT & .764 & .122 & .012 & 6.261 & .001 & .469 & 2.133 \\
\hline Y1 & 3.305 & .647 & .022 & 5.108 & .002 & .852 & 1.174 \\
\hline Y2 & .097 & .081 & .124 & 1.200 & .232 & .585 & 1.710 \\
\hline Y3 & -.041 & .080 & -.055 & -.515 & .608 & .543 & 1.841 \\
\hline Y4 & .038 & .081 & .049 & .467 & .641 & .574 & 1.741 \\
\hline Y5 & .073 & .081 & .098 & .910 & .364 & .535 & 1.868 \\
\hline
\end{tabular}

The results of Table 8 show a meaningful and positive relationship between earning management and change in management. Therefore, the second hypothesis of this survey is confirmed.

\subsection{The results of the third hypothesis: The relationship between change management and earnings forecast error}

To examine the first hypothesis of this survey we use Pearson correlation ratio between change management and earnings forecast error is as follows,

$$
\begin{cases}H_{0}: & \rho=0 \\ H_{1}: & \rho \neq 0\end{cases}
$$

The result of Pearson correlation ratio between these two variables is equal to 0.882 , which means there is a positive and meaningful relationship between these two variables. Table 9 shows details of our findings on basic statistics on the regression model.

\section{Table 9}

The results of basic statistics for the third hypothesis

\begin{tabular}{cccccc}
\hline Model & $\begin{array}{c}\text { Pearson } \\
\text { correlation }\end{array}$ & $\begin{array}{c}\text { Determinant } \\
\text { coefficient }\end{array}$ & $\begin{array}{c}\text { Adjusted } \\
\text { determinant }\end{array}$ & $\begin{array}{c}\text { Standard } \\
\text { error }\end{array}$ & $\begin{array}{c}\text { Durbin } \\
\text { Watson }\end{array}$ \\
\hline 1 & $.882^{\mathrm{a}}$ & .777 & .761 & 2.24823 & 1.579 \\
\hline${ }^{\mathrm{a}}$ Level of Significance $=5 \%$ & & & &
\end{tabular}


In addition, Table 10 shows details of our findings on ANOVA test

Table 10

The results of ANOVA test

\begin{tabular}{cccccc}
\hline Model & Sum of Square & Df & Mean square & F value & Sig. \\
\hline Regression & 2959.999 & 12 & 246.667 & 48.801 & $.000^{\mathrm{a}}$ \\
Residual & 849.161 & 168 & 5.055 & & \\
\hline Total & 3809.160 & 180 & & & \\
\hline${ }^{a}$ Level of Significance $=5 \%$ & & & &
\end{tabular}

One more time the results of ANOVA test indicate that there is a linear relationship between independent variable and dependent variable.

Table 11

The results of regression analysis

\begin{tabular}{|c|c|c|c|c|c|c|c|c|}
\hline \multirow{2}{*}{\multicolumn{2}{|c|}{$\begin{array}{c}\text { Non-standard coefficients } \\
\text { B }\end{array}$}} & \multicolumn{2}{|c|}{ Standard coefficient } & \multirow{2}{*}{$\begin{array}{l}\text { t-student } \\
\text { Beta }\end{array}$} & \multirow{2}{*}{ Sig, } & \multirow{2}{*}{ Collinearity Statistics } & \multirow[b]{2}{*}{ B } & \multirow[b]{2}{*}{ Coefficient } \\
\hline & & Coefficient & Beta & & & & & \\
\hline \multirow[t]{13}{*}{1} & (Constant) & 40.779 & 2.660 & & 15.332 & .000 & & \\
\hline & CEOCHANGEit & 3.642 & .370 & .069 & 9.847 & .000 & .832 & 1.201 \\
\hline & CEOCHANGEit1 & 1.010 & .089 & .042 & 11.322 & .000 & .961 & 1.040 \\
\hline & DEBT & 12.314 & 1.150 & .057 & 10.711 & .000 & .538 & 1.858 \\
\hline & ROA & 20.791 & 2.373 & .429 & 8.763 & .001 & .554 & 1.805 \\
\hline & LNASSET & 2.011 & .096 & .794 & 20.930 & .000 & .922 & 1.085 \\
\hline & SAMEDIR & 9.734 & 1.621 & .024 & 6.005 & .002 & .463 & 2.161 \\
\hline & DIRECT & 2.131 & .151 & .045 & 14.118 & .000 & .486 & 2.058 \\
\hline & Y1 & 3.737 & .392 & .018 & 9.544 & .001 & .861 & 1.162 \\
\hline & Y2 & .869 & .541 & .075 & 1.606 & .110 & .611 & 1.637 \\
\hline & Y3 & 1.101 & .543 & .097 & 2.026 & .044 & .582 & 1.719 \\
\hline & Y4 & .545 & .538 & .048 & 1.013 & .313 & .594 & 1.684 \\
\hline & Y5 & .633 & .553 & .055 & 1.146 & .254 & .574 & 1.742 \\
\hline
\end{tabular}

Finally, the results of our regression model confirms the existence of positive and meaningful relationship between change management and earning forecasted error leading us to conclude that the third hypothesis is confirmed.

\section{Conclusion}

In this paper, we have presented an empirical study to measure the effects of change in top management on earning management, earning forecasted error and risk default. The proposed study of this paper gathered the necessary data from Tehran Stock Exchange and using two measures of Pearson correlation as well as ordinary least square techniques, we have examined three hypotheses of the survey. The results have confirmed that there were positive and meaningful relationships between top management change and three mentioned factors.

\section{References}

Altman, E. I. (1968). Financial ratios, discriminant analysis and the prediction of corporate bankruptcy. The journal of finance, 23(4), 589-609.

Agarwal, V., \& Taffler, R. (2008). Comparing the performance of market-based and accountingbased bankruptcy prediction models. Journal of Banking \& Finance, 32(8), 1541-1551. 
Burgstahler, D., \& Dichev, I. (1997). Earnings management to avoid earnings decreases and losses. Journal of accounting and economics, 24(1), 99-126.

Bergstresser, D., \& Philippon, T. (2006). CEO incentives and earnings management. Journal of Financial Economics, 80(3), 511-529.

Brockman, P., \& Turtle, H. J. (2003). A barrier option framework for corporate security valuation. Journal of Financial Economics, 67(3), 511-529.

Brookman, J., \& Thistle, P. D. (2009). CEO tenure, the risk of termination and firm value. Journal of Corporate Finance, 15(3), 331-344.

Call, A. C., Chen, S., \& Tong, Y. H. (2009). Are analysts' earnings forecasts more accurate when accompanied by cash flow forecasts?. Review of Accounting Studies, 14(2), 358-391.

Dechow, P. M., Richardson, S. A., \& Tuna, I. (2003). Why are earnings kinky? An examination of the earnings management explanation. Review of Accounting Studies, 8(2), 355-384.

Degeorge, F., Patel, J., \& Zeckhauser, R. (1999). Earnings management to exceed thresholds. The Journal of Business, 72(1), 1-33.

Dechow, P. M., Sloan, R. G., \& Sweeney, A. P. (1995). Detecting earnings management. Accounting Review, 193-225.

Firth, M., Kwok, C. H. B., \& Keng, L. T. (1995). Accuracy of profit forecasts contained in IPO prospectuses. Accounting and Business Review, 2(1), 55-83.

Gong, J. J. (2011). Examining shareholder value creation over CEO tenure: A new approach to testing effectiveness of executive compensation. Journal of Management Accounting Research, 23(1), 1-28.

Hillegeist, S. A., Keating, E. K., Cram, D. P., \& Lundstedt, K. G. (2004). Assessing the probability of bankruptcy. Review of Accounting Studies, 9(1), 5-34.

Jog, V., \& McConomy, B. J. (2003). Voluntary disclosure of management earnings forecasts in IPO prospectuses. Journal of Business Finance \& Accounting, 30(1-2), 125-168.

Ohlson, J. (1980). Financial Ratios and the Probabilistic Prediction of Bankruptcy. Journal of Accounting Research, 19, 109-131.

Ting, W. (2011). Top management turnover and firm default risk: Evidence from the Chinese securities market. China Journal of Accounting Research, 4(1), 81-89. 